\title{
BEHAVIOUR OF NEW ODS ALLOYS UNDER SINGLE AND MULTIPLE DEFORMATION
}

\author{
OBNAŠANJE NOVIH ODS ZLITIN PRI ENOJNI IN VEČKRATNI \\ DEFORMACIJI
}

\author{
Bohuslav Mašek¹, Omid Khalaj ${ }^{1}$, Zbyšek Nový², Tomáš Kubina², Hana Jirkova1, \\ Jiř́i Svoboda ${ }^{3}$, Ctibor Stádler ${ }^{1}$ \\ ${ }^{1}$ The Research Centre of Forming Technology, University of West Bohemia, Univerzitní 22, 306 14, Pilsen, Czech Republic \\ ${ }^{2}$ COMTES FHT a.s., Průmyslová 995, 33441 Dobřany, Czech Republic \\ ${ }^{3}$ Institute of Physics of Materials, Academy of Sciences Czech Republic, Žižkova 22, 616 62, Brno, Czech Republic \\ khalaj@vctt.zcu.cz
}

Prejem rokopisa - received: 2015-07-01; sprejem za objavo - accepted for publication: 2015-11-13

doi: $10.17222 /$ mit.2015.156

\begin{abstract}
The application of innovative processing techniques to conventional raw materials can lead to new structural materials with specific mechanical and physical properties, which open up new possibilities of use in some areas of industry. The processing is enabled by powder metallurgy, which utilizes powders consisting of a metal matrix with dispersed stable particles achieved by mechanical alloying and their hot consolidation by rolling. New oxide dispersion strengthened (ODS) Fe-Al-based alloys are tested under different single and multiple thermomechanical treatments at different temperatures. The results show that new ODS alloys are significantly affected by the thermo-mechanical treatment, leading to microstructural changes. Their analysis is performed using different analytical methods such as optical microscopy, scanning electron microscopy and X-ray diffraction analysis.
\end{abstract}

Keywords: ODS alloys, composite, steel, Fe-Al

Uporaba inovativnih tehnik preoblikovanja na običajnih materialih lahko privede do novih konstrukcijskih materialov s specifičnimi mehanskimi in fizikalnimi lastnostmi, ki odpirajo nove možnosti uporabe v industriji. Metalurgija prahov omogoča uporabo prahov s kovinsko osnovo z dispergiranimi stabilnimi delci, ki jih dobimo pri mehanskem legiranju in vroči konsolidaciji z valjanjem. Nove zlitine Fe-Al, disperzijsko utrjene z oksidi (ODS), so bile preizkušene pri različni, eno- ali večstopenjski obdelavi pri različnih temperaturah. Rezultati kažejo, da ima termomehanska obdelava novih ODS zlitin močan vpliv, ki se vidi v spremembah mikrostrukture. Analiza je bila izvedena s pomočjo različnih analitskih metod, kot so: svetlobna mikroskopija, vrstična elektronska mikroskopija in rentgenska difrakcijska analiza.

Ključne besede: ODS zlitine, kompozit, jeklo, Fe-Al

\section{INTRODUCTION}

The demand to increase the efficiency of processes in most industrial applications requires, in many cases, metallic materials that can operate at high temperatures, and often at high stresses, in corrosive environments. The presently used high-temperature $\mathrm{Ni}-, \mathrm{Co}-$ and $\mathrm{Fe}-$ based alloys are strengthened by a combination of solidsolution and precipitation hardening, the effectiveness of which strongly decreases with increasing temperature. ODS alloys contain small amounts $(0.5-1 \%$ of weight fractions) of finely dispersed oxide phase (mostly yttrium), which is thermodynamically much more stable than other strengthening phases such as $\gamma^{\prime}$ or carbides, present in conventional high-temperature alloys. ${ }^{1}$ Therefore, the strengthening imparted by the oxide dispersions is retained up to very high temperatures because only limited coarsening or dissolution of the particles occurs. ${ }^{2,3}$ In addition, the presence of the fine dispersions combined with a very coarse-grained microstructure that is stable over long exposure times leads to excellent creep resistance up to higher temperatures than those that can be achieved with conventional wrought or cast alloys. ${ }^{4,5}$
The ODS alloys commercially produced at the end of the $20^{\text {th }}$ century and the beginning of the $21^{\text {st }}$ century are represented by MA 956 or MA $957^{6}$, PM 2000 or PM $2010^{6}$, ODM alloys ${ }^{7}$ and $1 \mathrm{DK}$ or $1 \mathrm{DS}^{8}$ with a ferritic matrix by ODS Eurofer steels with a tempered ferriticmartensitic matrix ${ }^{9}$ and by austenitic Ni-ODS PM 1000 or Ni-ODS PM 3030. ${ }^{10}$ ODS alloys are produced by high-energy milling of powder mixtures consisting of the alloying elements, master alloys and the oxide dispersion. The volume fraction of dispersed spherical oxides (usually $\mathrm{Y}_{2} \mathrm{O}_{3}$ ) is typically below $1 \%$ and the oxides are typically of a mean size of 5-30 nm. The mechanically alloyed powder is then consolidated at high temperatures and pressures to produce the bulk material in the form of bar or tube stock. Afterwards, different thermomechanical treatments are applied to optimize its microstructure and mechanical properties. In the consolidation step the processing temperatures are critical in order to retain the nanocrystalline structure generated during the mechanical alloying and to impede particle coarsening and grain growth. ${ }^{1-14}$ The Ni- and Fe-based ODS alloys rely on the formation of slowly growing and strongly 
adherent chromium and aluminium scales for their high-temperature oxidation/corrosion resistance. Because of the lower diffusion coefficient, austenitic ODS alloys show a better creep resistance for the same oxide volume fraction and contain some minimum chromium/ aluminium content to guarantee sufficient oxidation resistance. However, the resistance to the coarsening of oxides is given by the product of the solubility of oxygen in the matrix and its diffusion coefficient; ${ }^{16}$ this factor is more advantageous for ferritic ODS alloys. Also, a sufficient content of $\mathrm{Al}$ and/or $\mathrm{Cr}$ in the ODS alloy is decisive for its oxidation resistance. ${ }^{17-19}$ This is probably the reason why the application of ferritic ODS steels dominates. ${ }^{15-23}$

The new ODS alloys consist of a ferritic Fe-Al matrix strengthened with about 6 to $10 \%$ volume fractions of $\mathrm{Al}_{2} \mathrm{O}_{3}$ particles. ${ }^{24,25}$ In order to get a more detailed insight into these new groups of materials, an experimental programme was carried out to better understand their processing behaviour and their operational properties.

\section{EXPERIMENTAL PART}

Mechanically alloyed (MA) powders were prepared in a low-energy ball mill, developed by the authors (Figure 1), which enables evacuation and filling by oxygen. It has two steel containers (each $24 \mathrm{~L}$ ) and each container is filled with 80 steel balls of diameter $40 \mathrm{~mm}$. The revolution speed is variable between $20 \mathrm{~min}^{-1}$ to $75 \mathrm{~min}^{-1}$.

The mechanically alloyed powders consisting of Fe10wt $\% \mathrm{Al}$ matrix and $6 \%$ to $10 \%$ volume fractions of $\mathrm{Al}_{2} \mathrm{O}_{3}$ particles were deposited into a steel container of diameter $70 \mathrm{~mm}$, evacuated and sealed by welding (Figure 2). The steel container was heated up to a temperature of $800-900{ }^{\circ} \mathrm{C}$ and rolled by a hot-rolling mill (Figure 3) to a thickness of 20-25 $\mathrm{mm}$ in the first rolling step and then heated up to a temperature of $1100{ }^{\circ} \mathrm{C}$ and rolled to a thickness of $9 \mathrm{~mm}$ in the second step. A

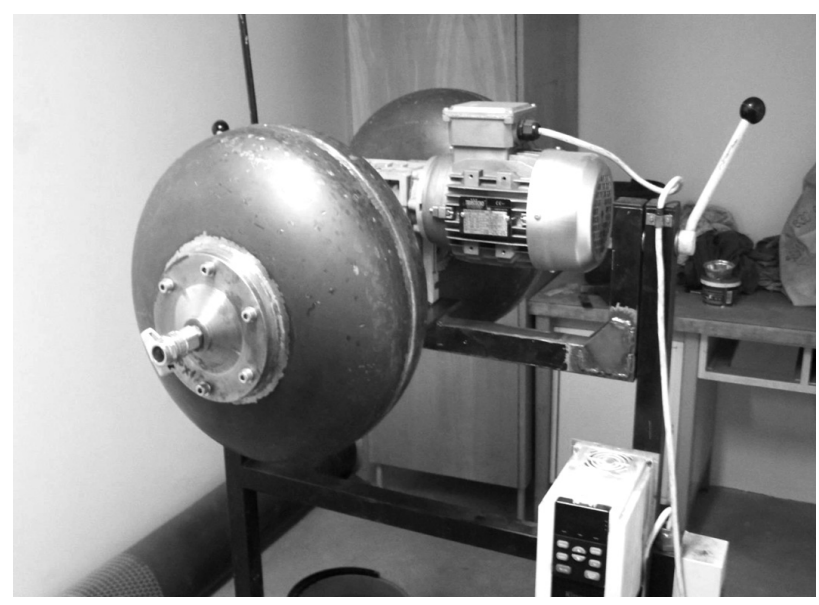

Figure 1: Low-energy mill for mechanical alloying Slika 1: Nizko energijski mlin za mehansko legiranje

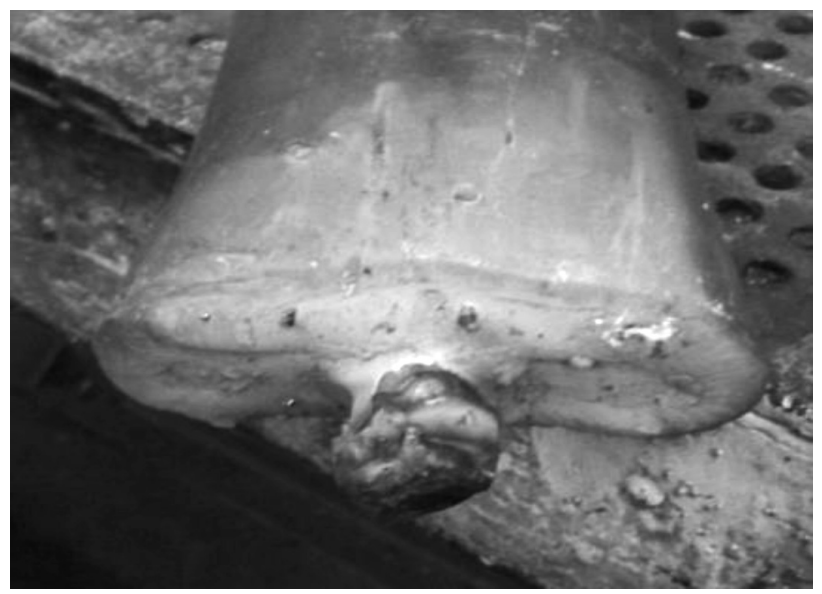

Figure 2: Container for mechanical alloyed powder Slika 2: Zbirnik za mehansko legiran prah

6-mm-thick sheet of the ODS alloy was produced in this way. Afterwards, the specimens were cut by water jet.

In order to investigate the thermomechanical treatment of specimens, a servohydraulic MTS thermomechanical simulator (Figure 4) was used, which allows the running of various temperature-deformation paths necessary to find conditions leading to, e.g., the most effective grain coarsening by recrystallization. Several
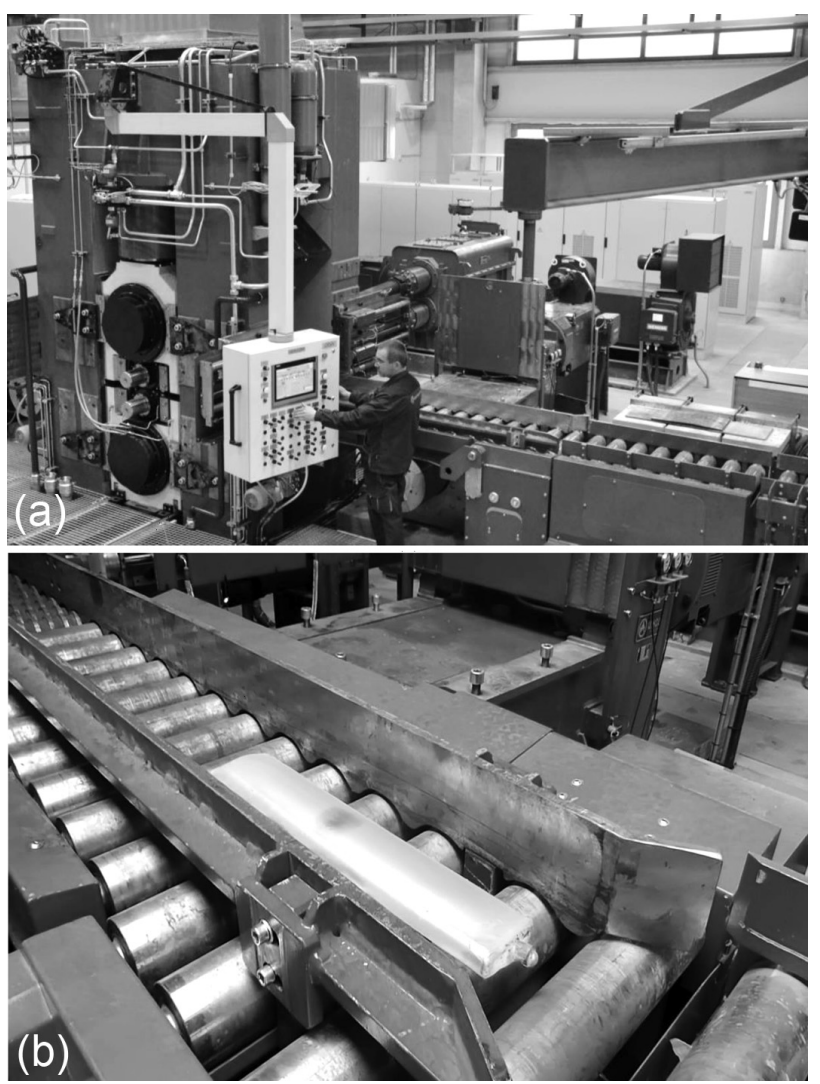

Figure 3: Rolling process: a) hot-rolling mill, b) steel container in rolling process

Slika 3: Valjanje: a) ogrodje za vroče valjanje, b) zbirnik med postopkom valjanja 


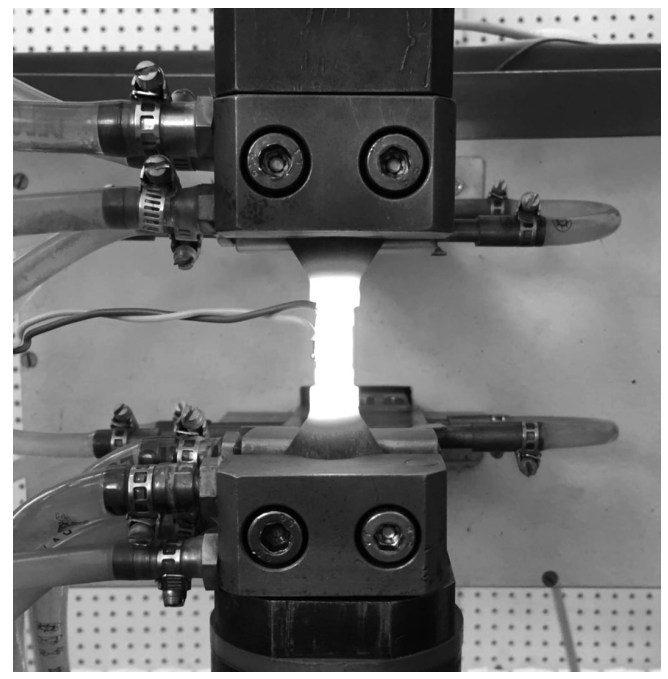

Figure 4: Treatment on thermomechanical simulator Slika 4: Obdelava na termomehanskem simulatorju

procedures of thermomechanical treatment were designed and carried out, which differed in the number of deformation steps characterized by different strains, strain rates and temperatures. The thermomechanical simulator also allows the combination of tensile and compressive deformation, thus accumulating a high plastic deformation (and a high dislocation density) in the specimen.

\subsection{Preparation of specimens}

One specimen (Figure 5) was selected from several examples regarding their most homogeneous temperature fields. The steel containers were removed from all the specimens that were cut by water jet in a longitudinal direction (Figure 6). The thickness of specimens was approximately $6 \mathrm{~mm}$ after grinding.

Six types of material were used in this research, as described in Table 1. All these materials are based on a Fe10wt\%Al ferritic matrix with different particle sizes and volume fractions in $\%$ of $\mathrm{Al}_{2} \mathrm{O}_{3} \cdot \mathrm{Al}_{2} \mathrm{O}_{3}$ powder was

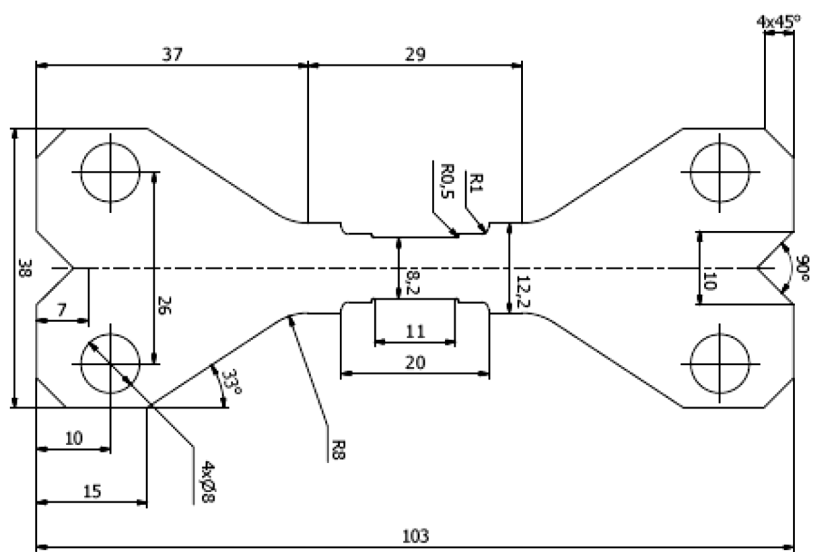

Figure 5: Specimen dimensions Slika 5: Dimenzije vzorca

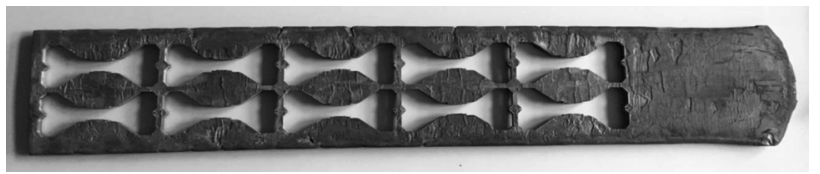

Figure 6: Position of specimens on rolled semi-product Slika 6: Položaj vzorcev na valjanem polproizvodu

added to prepare the composite, fine oxides in ODS alloys were obtained by internal oxidation during mechanical alloying and precipitated during hot consolidation. The microscopic SEM observations indicated several inhomogeneities due to sticking of the material during mechanical alloying on the walls of the milling container. These inhomogeneities can also influence the mechanical and fracture properties of the material, but the mechanical alloying process is steadily optimized with respect to the homogeneity of the materials.

Table 1: Material parameters

Tabela 1: Parametri materiala

\begin{tabular}{|c|c|c|c|c|c|}
\hline $\begin{array}{c}\text { Mate- } \\
\text { rial } \\
\text { No. }\end{array}$ & $\begin{array}{c}\text { Material } \\
\text { type }\end{array}$ & $\begin{array}{c}\text { Milling } \\
\text { time (h) }\end{array}$ & $\begin{array}{c}\text { Ferritic } \\
\text { matrix } \\
\left(\begin{array}{c}\% \text { of mass } \\
\text { fractions })\end{array}\right.\end{array}$ & $\begin{array}{c}\% \text { of } \\
\text { volume } \\
\text { fractions } \\
\text { of } \mathrm{Al}_{2} \mathrm{O}_{3}\end{array}$ & $\begin{array}{c}\text { Typical } \\
\text { particle } \\
\text { size } \\
(\mathrm{nm})\end{array}$ \\
\hline 1 & Composite & - & $\mathrm{Fe} 10 \% \mathrm{Al}$ & 10 & 300 \\
\hline 2 & ODS Alloy & 100 & $\mathrm{Fe} 10 \% \mathrm{Al}$ & 6 & $50-200$ \\
\hline 3 & ODS Alloy & 150 & $\mathrm{Fe} 10 \% \mathrm{Al}$ & 6 & $50-150$ \\
\hline 4 & ODS Alloy & 200 & $\mathrm{Fe} 10 \% \mathrm{Al}$ & 6 & $30-150$ \\
\hline 5 & ODS Alloy & 245 & $\mathrm{Fe} 10 \% \mathrm{Al}$ & 7 & $20-50$ \\
\hline $6 *$ & ODS Alloy & 245 & $\mathrm{Fe} 10 \% \mathrm{Al}$ & 7 & $20-50$ \\
\hline
\end{tabular}

* Different rolling force

\subsection{Testing programme}

The test programme was divided into six different series. The tests are summarized in Table 2.

Single deformation tests series were carried out to investigate the thermomechanical behaviour of the different materials ( 1 to 4 ) at different temperatures regarding single tensile loading with a constant strain rate of $1 \mathrm{~s}^{-1}$ (Figure 7). In order to give a clearer comparison of the results, only the results at room temperature (RT), $800{ }^{\circ} \mathrm{C}$ and $1200{ }^{\circ} \mathrm{C}$ are presented.

Multiple deformation-test series were carried out to investigate the thermomechanical behaviour of Materials

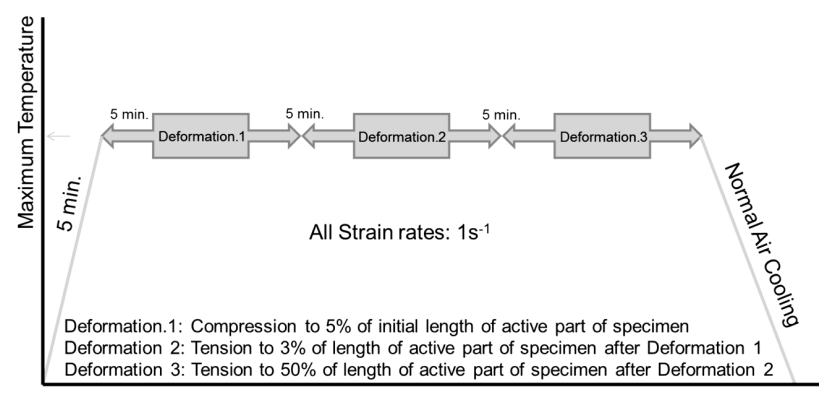

Figure 7: Treatment no. 1

Slika 7: Obdelava št. 1 
Table 2: Parameters of test programme

Tabela 2: Parametri programa preizkusa

\begin{tabular}{|c|c|c|c|c|c|c|}
\hline Test series & $\begin{array}{c}\text { Material } \\
\text { no. }\end{array}$ & Treatment no. & Treatment type & $\begin{array}{c}\text { Maximum } \\
\text { temperature }\left({ }^{\circ} \mathrm{C}\right)\end{array}$ & Number of tests & Purpose of tests \\
\hline A & 1 & 1 & Single & \multirow{4}{*}{$\begin{array}{l}1200,1100,1000 \\
900,800, \mathrm{RT}\end{array}$} & 6 & \multirow{4}{*}{$\begin{array}{c}\text { Single deformation } \\
\text { thermomechanical } \\
\text { behaviour }\end{array}$} \\
\hline $\mathrm{B}$ & 2 & 1 & Single & & 6 & \\
\hline $\mathrm{C}$ & 3 & 1 & Single & & 6 & \\
\hline $\mathrm{D}$ & 4 & 1 & Single & & 6 & \\
\hline $\mathrm{E}$ & 5 & 2 & Multiple & \multirow[b]{2}{*}{1200} & 2 & \multirow{2}{*}{$\begin{array}{c}\text { Multiple deformation } \\
\text { thermomechanical } \\
\text { behaviour }\end{array}$} \\
\hline $\mathrm{F}$ & 6 & 2 & Multiple & & 2 & \\
\hline
\end{tabular}

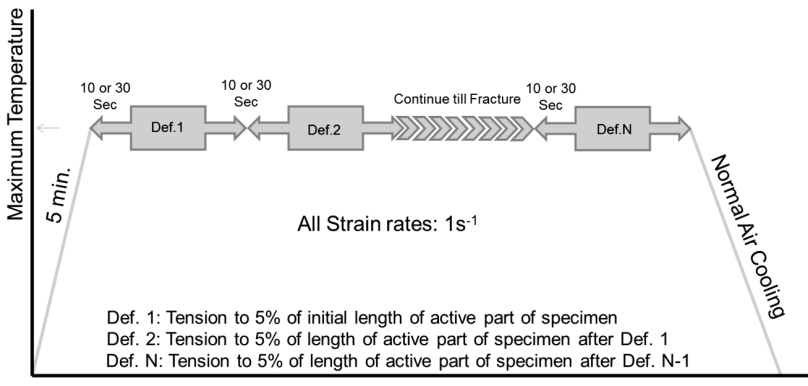

Figure 8: Treatment no. 2

Slika 8: Obdelava št. 2

5 and 6 at $1200{ }^{\circ} \mathrm{C}$ regarding multiple tensile loading with a constant strain rate of $1 \mathrm{~s}^{-1}$ (Figure 8) followed by two different holding times (10 $\mathrm{s}$ and $30 \mathrm{~s})$.

\section{RESULTS AND DISCUSSION}

\subsection{Single deformation-test series}

Single deformation-test series were carried out in order to investigate different materials under different conditions. Figure 9 shows the stress-strain curves for all the materials at different temperatures regarding the $5 \%$ compression corresponding to treatment number 1 . Material 2 exhibits a better strength at $30{ }^{\circ} \mathrm{C}$ and $800{ }^{\circ} \mathrm{C}$, but at $1200{ }^{\circ} \mathrm{C}$ Material 1 shows a better strength. The hot-working behaviour of alloys is generally reflected by flow curves, which are a direct consequence of microstructural changes: the nucleation and growth of new grains, dynamic recrystallization (DRX), the generation of dislocations, work hardening $(\mathrm{WH})$, the rearrangement of dislocations and their dynamic recovery (DRV). In the deformed materials, DRX seems to be the prominent softening mechanism at high temperatures. DRX occurs during the straining of metals at high temperature, characterized by nucleation of low-dislocation-density grains and their posterior growth to produce a homogeneous grain structure if a dynamic equilibrium is reached.

Material 4 showed a strange curve shape at $800{ }^{\circ} \mathrm{C}$. The test was repeated several times and similar behaviour was observed. It could be concluded that it happens because of the inhomogeneity of the microstructure of this material.
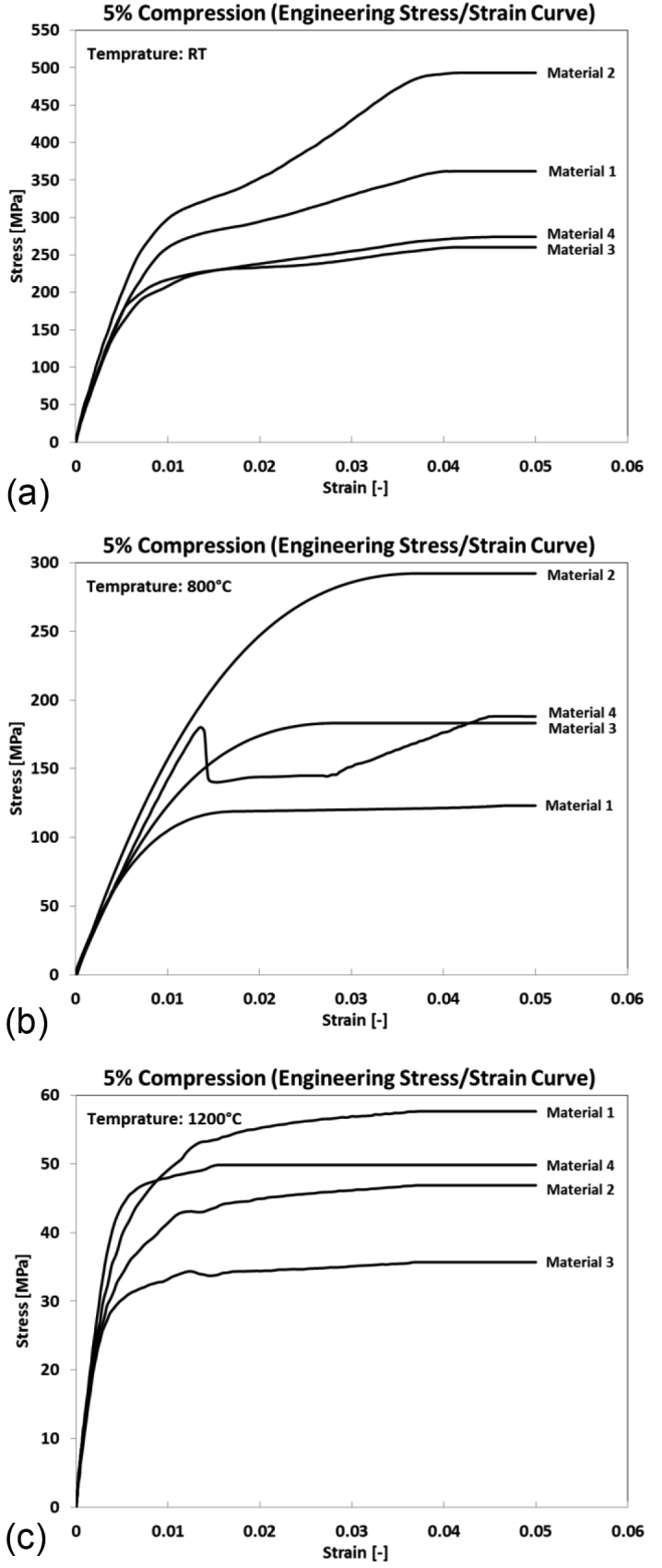

Figure 9: Stress-strain curves (5\% compression) for: a) RT, b) $800{ }^{\circ} \mathrm{C}$, c) $1200{ }^{\circ} \mathrm{C}$

Slika 9: Krivulje napetost-raztezek (5 \% stiskanje) za: a) RT, b) $800{ }^{\circ} \mathrm{C}$, c) $1200{ }^{\circ} \mathrm{C}$ 
Figure 10 shows the stress-strain curves for Materials 1 to 4 at different temperatures corresponding to the $3 \%$ tension of treatment number 1 (Figure 7). As can be seen in Figure 10, Material 2 shows a higher strength at $30{ }^{\circ} \mathrm{C}$ and $800{ }^{\circ} \mathrm{C}$, but at $1200{ }^{\circ} \mathrm{C}$, again Material 1 shows a better strength. All four materials have almost the same elastic modulus and none of them failed during $3 \%$ deformation. The yield stress as well as the shape of the flow curves is sensitive to temperature. Comparing all these curves, it is found that decreasing the deformation temperature increases the yield stress level, in other
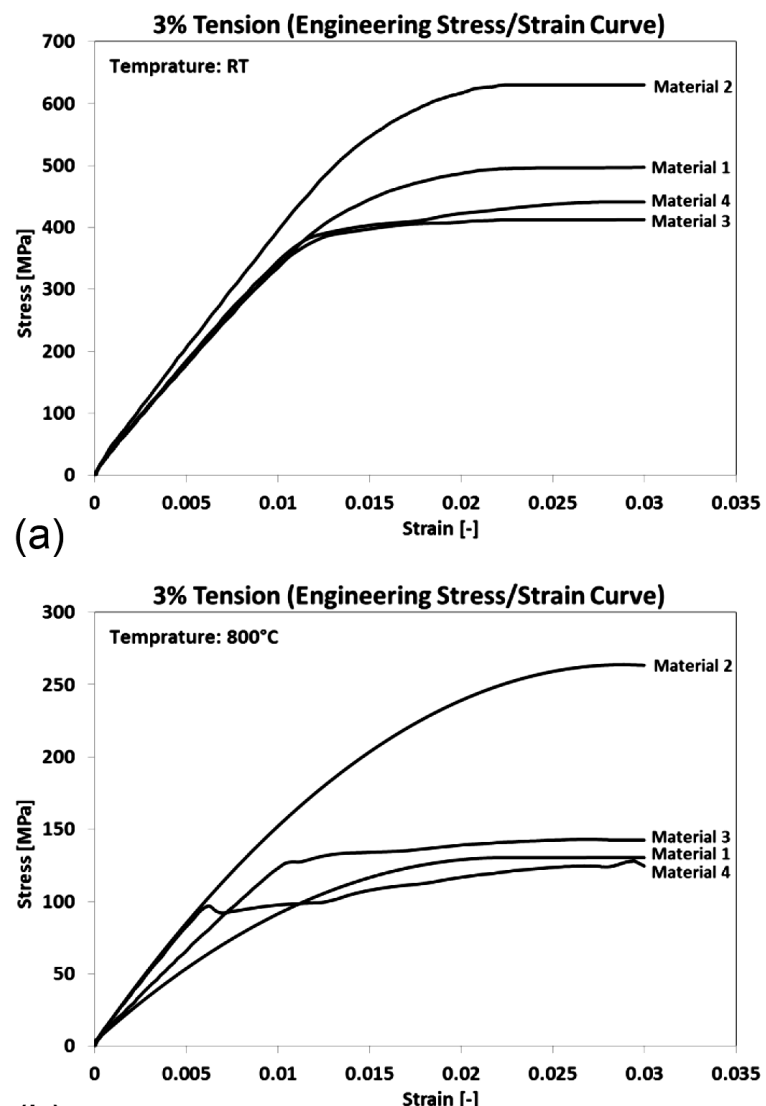

(b)

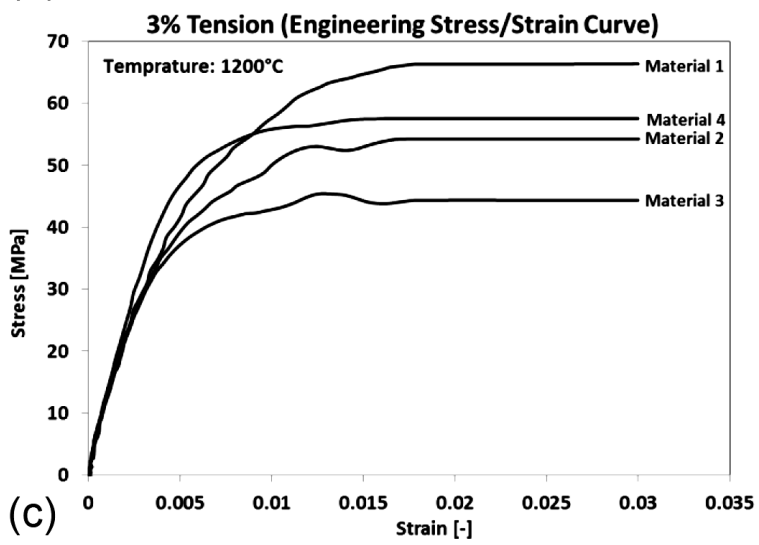

Figure 10: Stress-strain curves ( $3 \%$ tension) for: a) RT, b) $800{ }^{\circ} \mathrm{C}$, c) $1200{ }^{\circ} \mathrm{C}$

Slika 10: Krivulja napetost-raztezek ( $3 \%$ natezna obremenitev) za: a) RT, b) $800{ }^{\circ} \mathrm{C}$, c) $1200{ }^{\circ} \mathrm{C}$ words, it prevents the occurrence of softening due to dynamic recrystallization (DRX) and dynamic recovery (DRV) and allows the deformed metals to exhibit work hardening (WH). For every curve, after a rapid increase in the stress to a peak value, the flow stress decreases monotonically towards a steady-state regime with a varying softening rate, which typically indicates the onset of DRX (Figure 9c).

Figure 11 shows the stress-strain curves for Materials 1 to 4 at different temperatures corresponding to the $50 \%$ tension of treatment number 1 (Figure 7). All four
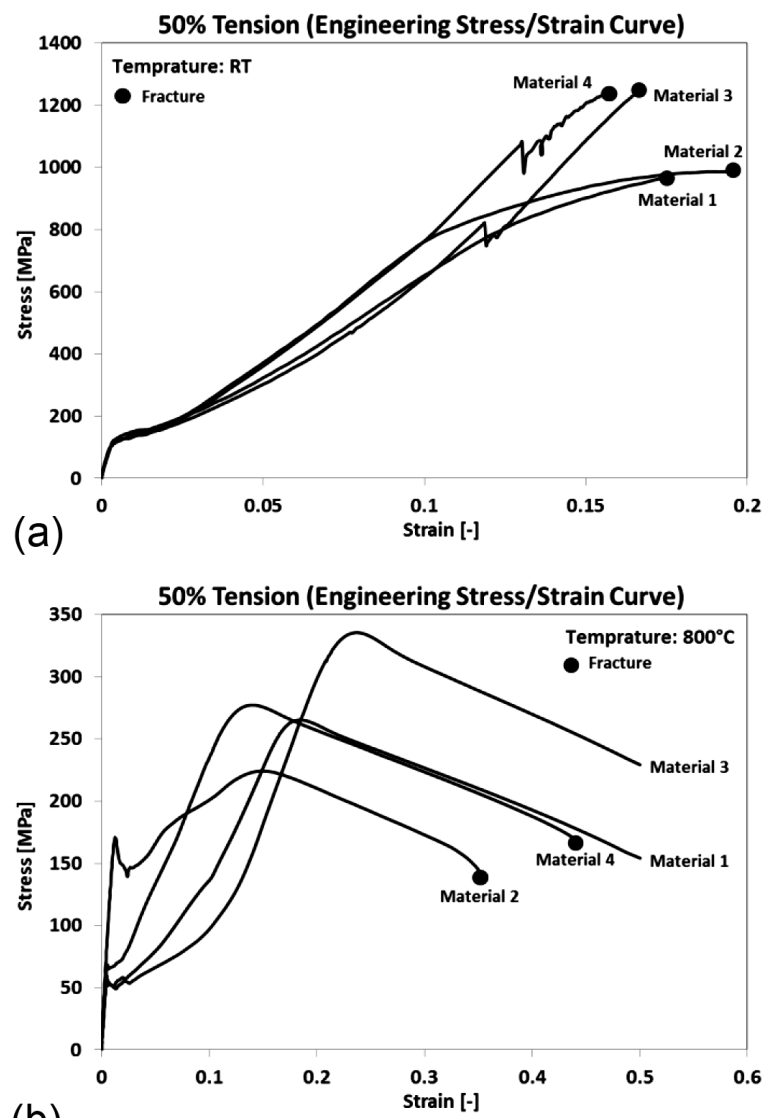

(b)

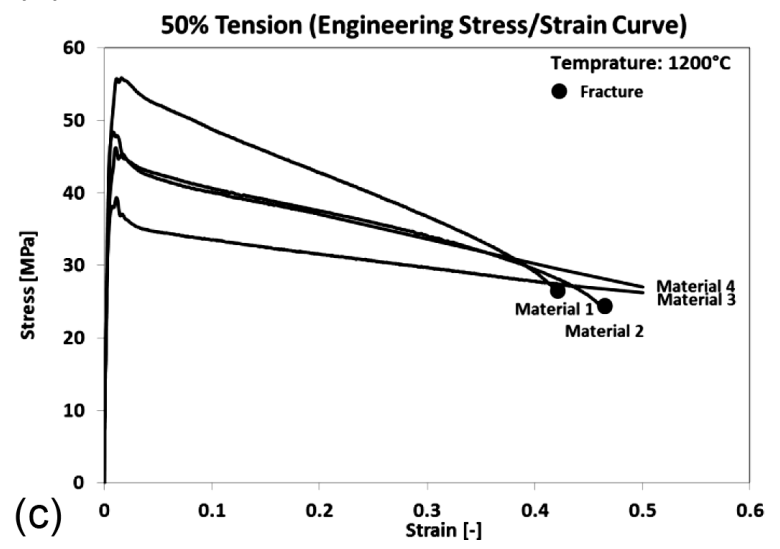

Figure 11: Stress-strain curves (50\% tension) for: a) RT, b) $800{ }^{\circ} \mathrm{C}$, c) $1200{ }^{\circ} \mathrm{C}$

Slika 11: Krivulja napetost-raztezek (50\% natezna obremenitev) za: a) RT, b) $\left.800{ }^{\circ} \mathrm{C}, \mathrm{c}\right) 1200{ }^{\circ} \mathrm{C}$ 
materials failed at RT, but only two materials failed below $50 \%$ tension at higher temperatures. Material 2 failed at $34 \%$ strain and Material 4 failed at $44 \%$ strain at $800{ }^{\circ} \mathrm{C}$. At $1200{ }^{\circ} \mathrm{C}$, only Material 1 failed at $41 \%$ and Material 2 failed at $45 \%$ strain. From these curves, it can also be seen that the stress evolution with strain exhibits three distinct stages.

In the first stage work hardening (WH) predominates and causes dislocations to polygonize into stable subgrains. Flow stress exhibits a rapid increase with increasing strain up to a critical value. Then DRX occurs due to a large difference in dislocation density within the subgrains or grains. When the critical driving force of DRX is attained, new grains are nucleated along the grain boundaries, deformation bands and dislocations, resulting in the formation of equiaxed DRX grains.

In the second stage, flow stress exhibits a smaller and smaller increase until a peak value or an inflection of the work-hardening rate is reached. This shows that the thermal softening due to DRX and dynamic recovery (DRV) becomes more and more important and it exceeds WH.

In the third stage, three types of curves can be recognized:

- Decreasing gradually to a steady state with DRX softening (Material $3 \& 4$ in Figure 11c),

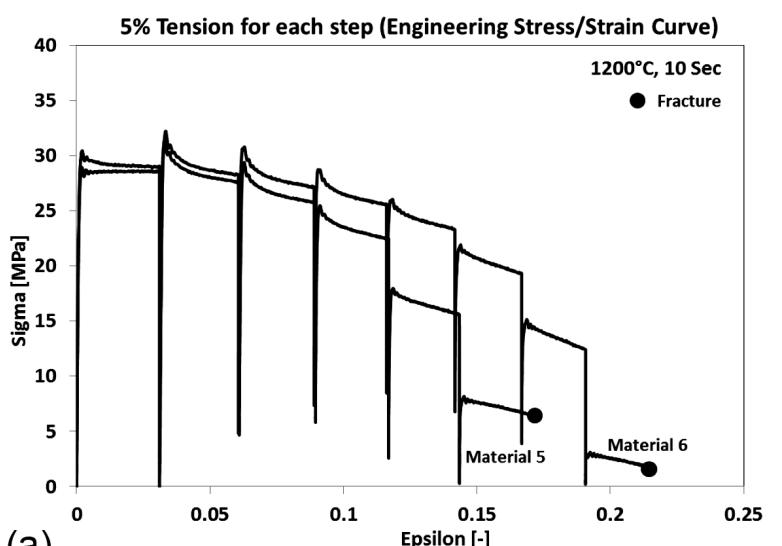

(a)

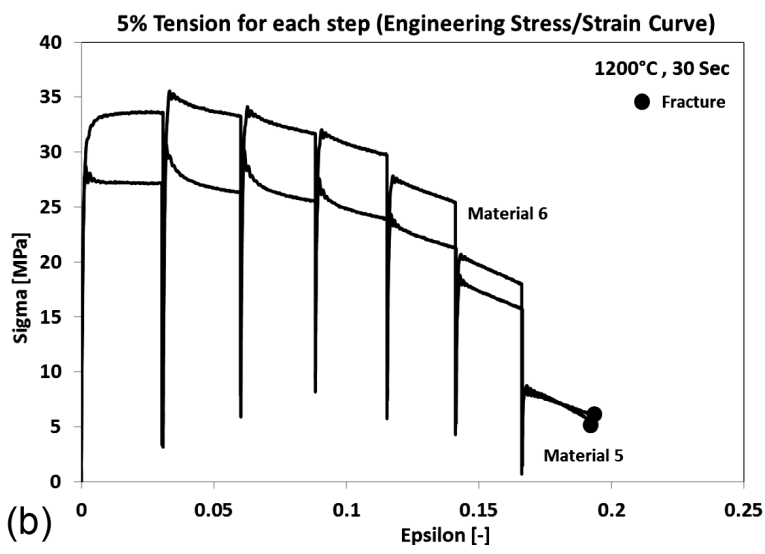

Figure 12: Stress-strain curves (5\% tension) for: a) holding time $10 \mathrm{~s}$, b) holding time $30 \mathrm{~s}$

Slika 12: Krivulja napetost-raztezek ( pri $5 \%$ natezni obremenitvi) za: a) čas zadržanja $10 \mathrm{~s}$, b) čas zadržanja $30 \mathrm{~s}$
- Increasing continuously with significant work-hardening (Material 1 \& 2 in Figure 11b),

- Decreasing continuously with significant DRX softening.

\subsection{Multiple deformation-test series}

Multiple deformation-test series were carried out in order to investigate the material behaviour under various conditions. Figure 12 shows the stress-strain curves for both materials at different holding times following the 5 $\%$ tension during treatment number 2 (Figure 8). Both materials show approximately the same behaviour under the multiple tensile loading. However, Material 6 exhibits greater strength for both holding times $(10 \mathrm{~s}$ and $30 \mathrm{~s}$ ). It is supposed that the oxide particles prevent undesirable cyclic softening, which is observed in ferriticmartensitic steels. ${ }^{22}$ Obviously, the oxide particles strengthen the material substantially, nevertheless, cyclic softening is observed at both holding times. The cyclic softening rate depends on the applied loading. A higher strain amplitude results in a higher softening rate. For instance, the softening rate was about $23 \%$ during the second cycle in Material 5, while it decreased to $12 \%$ during the last cycles. Although the softening in ODS steel is lower than in the ferritic-martensitic steel ${ }^{26}$, it indicates that oxide dispersion itself does not guarantee a stable cyclic behaviour and other microstructural aspects have to be taken into account. It is obvious that the stress amplitude decreased with an increasing number of cycles, while the amplitude of the plastic strain increased. The softening rate in Material 6 is lower than in Material 5, as observed for both holding times. The slight cyclic hardening is observed only during the first cycle in Material 6 with 30 s holding time (Figure 12b), while continuous softening behaviour is observed in the remaining part of the curve.

\section{CONCLUSIONS}

This paper outlines the results of the characterization of the single and multiple deformation thermomechanical behaviour of a new generation of ODS alloys. Six materials differing from each other in the amount and size of the oxides embedded in the ferritic matrix were tested under different conditions. The advantages of all the materials are their low-cost and creep-corrosion and oxidation-resistance due to the Fe-Al-based ferritic matrix of the ODS alloy. It can be concluded that in general the oxide dispersion significantly strengthens the material. However, the typical form of the flow curve with DRX softening, including a single peak followed by a steady state flow as a plateau, is more recognizable at high temperatures than at low temperatures. This is because at high temperatures the DRX softening compensates the WH, and both the peak stress and the onset of steady-state flow are therefore shifted to lower strain levels. The characteristics of softening flow behaviour coupled with DRX have been discussed for six materials and can be summarized as follows: 
1. Decreasing deformation temperature causes the flow stress level to increase, in other words, it prevents the occurrence of softening due to DRX and dynamic recovery (DRV) and makes the deformed metals exhibit work hardening (WH).

2. For every curve, after a rapid increase in the stress to a peak value, the flow stress decreases monotonically towards a steady-state regime (a steady-state flow as a plateau due to DRX softening is more recognizable at higher temperatures). A varying softening rate typically indicates the onset of DRX, and the stress evolution with strain exhibits three distinct stages.

3. At higher temperatures, a higher DRX softening compensates the $\mathrm{WH}$, and both the peak stress and the onset of steady-state flow are therefore shifted to lower strain levels.

4. The ODS alloy exhibits cyclic softening in most of the tests and its rate decreases with increasing strain.

5. The elastic part of the total strain amplitude is always higher than the plastic one in all the specimens tested, even for the highest total strain amplitudes of $15 \%$. This is further confirmation of the strong strengthening effect of oxide particles.

\section{Acknowledgements}

This paper includes results created within the projects 14-24252S Preparation and Optimization of Creep Resistant Submicron-Structured Composite with Fe-Al Matrix and $\mathrm{Al}_{2} \mathrm{O}_{3}$ Particles subsidised by the Czech Science Foundation, and LO1412 Development of West-Bohemian Centre of Materials and Metallurgy subsidised by the Ministry of Education, Youth and Sports from specific resources of the state budget of the Czech Republic for research and development.

\section{REFERENCES}

${ }^{1}$ M. Mohan, R. Subramanian, Z. Alam, P. C. Angelo, Evaluation of the Mechanical Properties OF A Hot Isostatically Pressed YttriaDispersed Nickel-Based Superalloy, Material Technology, 48 (2014) 6, 899-904

${ }^{2}$ W. Quadakkers. Oxidation of ODS alloys. Journal de Physique IV, 03 (1993), C9-177-C9-186, doi:10.1051/jp4:1993916

${ }^{3}$ F. Pedraza, Low Energy-High Flux Nitridation of Metal Alloys: Mechanisms, Microstructures and High Temperatures Oxidation Behaviour, Materials and technology, 42 (2008) 4, 157-169

${ }^{4}$ M. A. Montealegre, J. L. González-Carrasco, M. A. Morris-Muñoz, J. Chao, D. G. Morris, High Temperature Oxidation Behaviour of an ODS FeAl Alloy, Intermetallics, 8 (2000), 439-446, doi:10.1016/ S0966-9795 (99)00168-5

${ }^{5}$ B. Šuštaršic, I. Paulin, M. Godec, S. Glodez, M. Šori, J. Flašker, A. Korošec, S. Kores, G. Abramovic, Morphological and Microstructural Features of Al-based Alloyed Powders for Powder-metallurgy Applications, Materials and technology, 48 (2014) 3, 439-450

${ }^{6}$ B. Kazimierzak, J. M. Prignon, R. I. Fromont, An ODS Material with Outstanding Creep and Oxidation Resistance above $1100^{\circ} \mathrm{C}$, Materials and Design, 13 (1992) 2, 67-70, doi:10.1016/02613069(92)90109-U
${ }^{7}$ S. Ukai, M. Harada, H. Okada, M. Inoue, S. Nomura, S. Shikakura, T. Nishida, M. Fujiwara, K. Asabe, Tube Manufacturing and Mechanical Properties of Oxide Dispersion Strengthened Ferritic Steel, Journal of Nuclear Materials, 204 (1993), 74-80, doi:10.1016/ 0022-3115(93)90201-9

${ }^{8}$ R. Schaeublin, T. Leguey, P. Spätig, N. Baluc, M. Victoria, Microstructure and Mechanical Properties of Two ODS Ferritic/Martensitic Steels, Journal of Nuclear Materials, 307-311 (2002), 778-782, doi:10.1016/S0022-3115(02)01193-5

${ }^{9}$ F. D. Fischer, J. Svoboda, P. Fratzl, A thermodynamic approach to grain growth and coarsening, , Journal of Philosophical Magazine, 83 (2003) 9, 1075-1093, doi:10.1080/0141861031000068966

${ }^{10}$ M. J. Alinger, G. R. Odette, D. T. Hoelzer, On the role of alloy composition and processing parameters in nanocluster formation and dispersion strengthening in nanostuctured ferritic alloys, Acta Material, 57 (2009) 2, 392-406, doi:10.1016/j.actamat.2008.09.025

${ }^{11}$ P. Unifantowicz, Z. Oksiuta, P. Olier, Y. de Carlan, N. Baluc, Microstructure and mechanical properties of an ODS RAF steel fabricated by hot extrusion or hot isostatic pressing, Fusion Engineering and Design, 86 (2011), 2413-2416, doi:10.1016/j.fusengdes. 2011.01.022

${ }^{12}$ M. A. Auger, V. de Castro, T. Leguey, A. Muñoz, R. Pareja, Microstructure and mechanical behavior of ODS and non-ODS $\mathrm{Fe}-14 \mathrm{Cr}$ model alloys produced by spark plasma sintering, Journal of Nuclear Materials, 436 (2013) 5, 68-75, doi:10.1016/j.jnucmat. 2013.01.331

${ }^{13}$ M. Kos, J. Ferces, M. Brnucko, R. Rudolf, I. Anzel, pressing of Partially Oxide-Dispersion-Strenghtened Copper using the ECAP Process, Materials and technology, 48 (2014) 3, 379-384

${ }^{14}$ I. Kubena, B. Fournier, T. Kruml, Effect of Microstructure on Low Cycle Fatigue Properties of ODS Steels, Journal of Nuclear Materials, 424 (2012) 1-3, 101-108, doi:10.1016/j.jnucmat.2012. 02.011

${ }^{15}$ M. C. Brandes, L. Kovarik, M. K. Miller, G. S. Daehm, M. J. Mills, Creep Behavior and Deformation Mechanisms in a Nanocluster Strengthened Ferritic Steel, Acta Materialia, 60 (2012) 4, 1827, doi:10.1016/j.actamat.2011.11.057

${ }^{16}$ M. C. Brandes, L. Kovarik, M. K. Miller, M. J. Mills, Morphology, Structure, and Chemistry of Nanoclusters in a Mechanically Alloyed Nanostructured Ferritic Steel , Journal of Materials Science, 47 (2012) 8, 3913-3923, doi:10.1007/s10853-012-6249-x

${ }^{17}$ B. Fournier, A. Steckmeyer, A.-L. Rouffié, J. Malaplate, J. Garnier, M. Ratti, P. Wident, L. Ziolek, I. Tournié, V. Rabeau, J. M. Gentzbittel, T. Kruml, I. Kubena, Mechanical Behaviour of Ferritic ODS Steels - Temperature Dependency and Anisotropy, Journal of Nuclear Materials, 430 (2012) 1-3, 142-149, doi:10.1016/j.jnucmat. 2012.05.048

${ }^{18}$ M. Palm, Concepts Derived from Phase Diagram Studies for the Strengthening of Fe-Al-based Alloys, Intermetallics, 13 (2005) 12, 1286-1295, doi: 10.1016/j.intermet.2004.10.015

${ }^{19}$ F. Stein, M. Palm, G. Sauthoff, Mechanical Properties and Oxidation Behaviour of Two-Phase Iron Aluminium Alloys with $\mathrm{Zr}(\mathrm{Fe}, \mathrm{Al})$ Laves Phase or $\mathrm{Zr}(\mathrm{Fe}, \mathrm{Al}) 12 \tau 1$ Phase, Intermetallics, 13 (2005) 12, 1275-1285, doi:10.1016/j.intermet.2004.08.013

${ }^{20}$ D. G. Morris, M. A. Muñoz-Morris, Development of Creep-Resistant Iron Aluminides, Materials Science and Engineering A, 462 (2007), 45-52, doi:10.1016/j.msea.2005.10.083

${ }^{21}$ S. Milenkovic, M. Palm, Microstructure and Mechanical Properties of Directionally Solidified Fe-Al-Nb Eutectic, Intermetallics, 16 (2008) 10, 1212-1218, doi:10.1016/j.intermet.2008.07.007

${ }^{22}$ D. G. Morris, Possibilities for high-temperature strengthening in iron aluminides, Intermetallics, 6 (1998), 753-758, doi:10.1016/S09669795(98)00028-4

${ }^{23}$ M. A. Morris-Muñoz, Creep Deformation of Oxide-DispersionStrengthened Fe-40Al, Intermetallics, 7 (1999) 6, 653-661, doi:10.1016/S0966-9795(98)00079-X 
B. MAŠEK et al.: BEHAVIOUR OF NEW ODS ALLOYS UNDER SINGLE AND MULTIPLE DEFORMATION

${ }^{24}$ I. Kubena, T. Kruml, Fatigue life and microstructure of ODS steels, Eng. Fract. Mech., 103 (2013), 39-47, doi:10.1016/j.engfracmech. 2012.10. 011

${ }^{25}$ O. Khalaj, B. Mašek, H. Jirkova, A. Ronesova, J. Svoboda, Investigation on New Creep and Oxidation Resistant Materials, Materials and technology, 49 (2015) 4, 173-179, doi:10.17222/mit.2014.210

${ }^{26}$ P. Marmy, T. Kruml, Low cycle fatigue of Eurofer 97, Journal of Nuclear Materials, 377 (2008) 1, 52-58, doi:10.1016/j.jnucmat. 2008.02.054 